\title{
EVALUATION OF COMMUNICATION SKILLS OF HISTORICAL BAZAAR TRADESMEN: A RESEARCH ON FOREIGN TOURISTS VISITING EDIRNE
}

\author{
Abdullah USLU* \\ Akdeniz University, Faculty of Manavgat Tourism, Departmant of Tourism \\ Management, 07600 Manavgat/Antalya, Turkey, e-mail: auslu@akdeniz.edu.tr \\ Yeliz PEKERŞEN \\ Necmettin Erbakan University, Faculty of Tourism, 42090 Konya, Turkey, e-mail: yeliz.ulusan@gmail.com \\ Ayça TUNCA \\ Necmettin Erbakan University, Institute of Social Sciences, 42090 Konya, Turkey, e-mail: aycatunca95@gmail.com
}

\begin{abstract}
Citation: Uslu, A., Pekerşen Y., \& Tunca A. (2020). EVALUATION OF COMMUNICATION SKILLS OF HISTORICAL BAZAAR TRADESMEN: A RESEARCH ON FOREIGN TOURISTS VISITING EDIRNE. GeoJournal of Tourism and Geosites, $30(2 \mathrm{spl}), 835-842$. https://doi.org/10.30892/gtg.302spl08-512
\end{abstract}

\begin{abstract}
Tourism sector is a people-oriented sector. Communication, which is an important element in this sector, plays an important role for the tourists coming to the country to prefer the visited destination again. This research aims to determine how foreign tourists evaluate the communication skills of the tradesmen active in the historical bazaars of Alipaşa, Arasta and Bedesten in Edirne. For this purpose, survey data collected from 283 foreign tourists has been analyzed in SPSS 22.0 statistics program. As a result of the study, it has been found that the level of evaluation of the communication skills of the foreign tourists was good and also the evaluation of the communication skills of the foreign tourists had an effect on the satisfaction level of the communication skills of the tradesmen.
\end{abstract}

Key words: Communication skills, satisfaction, foreign (Bulgarian and Greek) tourist, Edirne

\section{INTRODUCTION}

Developing customer relationships are critical components in the success of service marketing (Kang and Hyun, 2012). Although communication is an important concept for all sectors, it is more critical in the human-oriented tourism sector for success (Erkuş and Günlü, 2009). Providing service not only requires skilfulness in dealing with the customer to leave good impression but also requires communication skills in dealing with the problems (Masa'deh et al., 2019). Communication skills in the dialogues established by individuals regardless of the unit of the tourism sector may affect tourists positively or negatively against that destination.

Nowadays, there is an increase in innovative research that helps to provide insight into the motivation and satisfaction levels of tourists (Hui et al., 2007). The increase in these researches and the way they are conducted show us the link between communication, tourism and customer satisfaction. Good communication skills of the people who produce and market tourist products in a destination can affect the increase in the satisfaction level of tourists and the desire to visit the province again (Olcay and Giritlioğlu, 2014). With a total of six border crossings opening to Greece and Bulgaria through both railway and highway, Edirne is a province that has the qualifications of a boundary province adjacent to Europe (Kar, 2012). The cultural and historical riches it contains make it a museum city (Akay et al., 2017). However, Edirne is one of the cities where tourism is developing slowly despite its cultural background and natural beauties. In this context, the aim of this study is to determine how the foreign tourists visiting Edirne perceive the communication skills of tradesmen operating in Ali Pasha Bazaar, Bedesten Bazaar and Arasta Bazaar. The study is important in that no similar research has been conducted in Edirne.

\section{LITERATURE REVIEW}

Communication Concept- Communication Elements and Methods

Communication is the driving force of the human being who is a social creature (Parlayan and Dökme, 2016) by introducing and communicating with other living things (Johnson, 1999). At the center of communication, which is the means of connecting people with each other, is the process of belonging, sharing and connecting (Collier et al., 2010). Communication is the desire of the person who starts or communicates to convey his/her feelings, thoughts and knowledge effectively and to be understood (Baltaş and Baltaş, 2004). Thayer (1961) considers communication as a thought and states that communication and thought processes form an inseparable in tegrity. Ruesch and Bateson (1951) have included feeling to Thayer's (1961) definition, noting that communication, thoughts and emotions are connected with each other. Shannon and Weaver (1949) describe communication as the procedure by which words and various symbols are used to influence and change other people around us, one mind affecting another. Communication, which is at the beginning of people's revolutionary discoveries, has the basic meaning of humanity at its center (Pearce, 1989).

The concept of communication, which has been systematically examined since antiquity (Littlejohn and Foss, 2011), has become an important issue with the development of technology across continents (Brown, 2005). The most general definition of communication is that a sender who has the ability to write or speak conveys verbal or written messages to any recipient who has the characteristics of listening or reading and this message being decoded by the recipient (Uzuntaş, 2013). The communication process consists of four basic elements: sender, message, receiver and channel (Bolat, 1996). The sender or the source, as the other definition in the liter ature, is the one who decides how and in which ways the message to be sent to the recipient will be sent (O'Hair et al., 2005). Examples of senders include teachers who teach in class, people who broadcast television or radio (Sezgin and Akgöz, 2009). The message element is the message that acts as a bridge between the sender and the receiver and determines the successful communication (Gökçe, 2006).

\footnotetext{
* Corresponding author
} 
The message is shaped as verbal and non-verbal, from the words the transmitter wants to tell, to the clothes s/he wears, even as his/her walking and laughing (DeVitto, 2004). Channel is the physical means by which signals and messages are transmitted in the communication process (Fiske, 1996). The person or groups who understand and interpret the message sent by the sender through the channel are the recipients. The receiver, students in class listening to the class, people watching television or listening to the radio can be given as an example (Gökçe, 2006). Communication takes place in three different ways: verbal, non-verbal and written (Boone and Kurtz, 1978). During the daily encounters, individuals mostly communicate by verbal way of speaking (Lazar, 2001). When communication takes place with words, it is regarded as verbal. Although verbal or nonverbal communication is interdependent, nonverbal communication is used to support or change verbal communication (Johnson, 1999). Verbal communication is a natural process due to the parallel develop ment of sound and language since the existence of humanity. Verbal communication is the most commonly used form of communication in every field of communication, in our daily relations, in professional fields and in diplomacy (Erdönmez, 2019).

Nonverbal communication supports the real meaning of verbal communication, the perception of the meanings expressed by the words and what they tell (Gökçe, 2006). Nonverbal communication is a type of communication that is carried out only by body language movements without using a word (Misırl1, 2007). Body language, which stands behind nonverbal communication (Poon Teng Fatt, 1998), provides a clue in analyzing characters as a personal signature (Davis, 1983). Written communication is the transmission of emotions, thoughts, wishes and events in an effective way in writing (Deniz, 2003). In written communication, the content plan is prepared in accordance with the purpose of the text and the thoughts are transferred to the text in accordance with this plan (Hamzaday1 and Cetinkaya, 2011) and includes special or official reports, letters, telegrams, bulletins, informative reports showing the results of organizational activities and decisions (Tutar et al., 2003). Additionally soft skills are basic fundamental of an important skill in human's lives (Sugito et al., 2017). Soft skills include interpersonal and personal attributes that enhance an individual's interactions, job performance and career prospects (Vasanthakumari, 2019). Soft skills should be given precedence as these play an important role in the tourism industry (Shabir and Sharma, 2019). In addition, it can affect relationships in effective and ineffective behaviors in communication. These behaviors that affect communication may be psychological factors stemming from the individuals or groups involved in the communication process, as well as the means of communication, communication channels and technical factors for message (Bolat, 1996).

\section{Relationship between Communication Skills and Satisfaction}

Customer satisfaction concept is the effect and emotion of the purchased product or service to the buyer (Cadotte et al., 1987). Many factors, including personal experiences, daily life and social values of customers (Mavis et al., 2010), affect the perception of a product or service, purchasing behavior and customer satisfaction (Yılmaz and Çatalbaş, 2007). As a natural result of meeting the customer expectations with the services and products they offer, customer satisfaction (Cronin and Taylor, 1992) helps to provide competitive advantage in terms of business (Day, 1994). In order to increase the profitability of enterprises, customer satisfaction should be ensured as a priority case study (Stewart et al., 1998). The poor communication is perhaps the most common problem among service businesses (Krishnan and Wesley, 2013). Customer satisfaction, which is at the forefront of service businesses (Jones and Sasser, 1995), helps businesses gain new customers by positively affecting their perceived image (Zairi, 2000). With the development of technology, customers share their experiences with each other about the products and services offered (Briggs et al., 2007).

The service-oriented sector of tourism products and services produced to meet the needs of tourists in a quality way plays an important role in ensuring tourist satisfaction (Bahar and Kozak, 2005). Since human relations are at the forefront in tourism enterprises (Günlü, 2001), effective and accurate communication provides an increase in customer satisfaction levels.

\section{Edirne Province and Its Tourism Potential}

Edirne province was founded on the fertile soils where Arda (Arpessos), Tunca (Tonzos) and Meriç (Herbos) rivers meet by the Thracians who migrated from Central Asia in the 5th century BC (Edirne Province Yearbook, 2005). It is located at a key point between Central Europe and the main road descending to the Bosporus from the earliest times up to today (Mansel, 1993). The city, which was first named Uscudama and Oreistias by the Thracians, was taken under the patronage of Rome in 124 AD and had its changed name to Hadrianopolis (Eyice, 1993). Until its conquest by the Ottoman Empire in 1361, it remained under the rule of the Roman and Byzantine Empires, respectively (Gizerler, 2004). It served as the capital of the Ottoman Empire for approximately 92 years and until the conquest of Istanbul in 1453, it was among the cultural centers as the center of science, culture and art of the empire (Erdogan and Kuter, 2010).

Examples of civil architecture such as religious, socio-cultural, educational and minority structures are among the components of the city's artificial identity (Misirl et al., 2019). Edirne is a city that still exhibits some of its cultural and historical riches and hosts many people from different cultures and races for centuries (Can and Bilar, 2009). The mindset that the province follows in terms of culture differs considerably compared to the mindset of other Anatolian cities (Usal, 2006). Although Edirne has lost most of its historical monuments it still has the characteristics of a museum city (Akay et al., 2017). Selimiye Mosque and Complex, which was included in the World Heritage List by UNESCO World Heritage Committee in 2011 (Bilar, 2015), is regarded as the masterpiece of Sinan the Architect and is among the most remarkable buildings in the city with its elegance (Taylor, 1998). Another remarkable structure of Edirne, which is the pioneer of modern hospitals and has been serving as a health museum since 1997, is Sultan Bayezid II Complex (Heybeli, 2009).

In addition to the architectural and historical artifacts, historical Kırkpinar Greased Wrestling is organized every year for 657 years in Edirne (Küçükaltan et al., 2005). With its addition to UNESCO Intangible Cultural Heritage of Humanity by Turkey in 2010 (Ministry of Culture and Tourism, 2019), many domestic and foreign participants visit the event (Küçükaltan et al., 2005). In addition, the Directorate of Culture and Tourism and Edirne Municipality organize "Traditional Homemade Food" competitions every year at the Historical Kirkpınar Festivals. In the competition, almond paste, liver pan, liver wrap and deva-i musk paste are among the local delicacies of the city (Gizerler, 2004). Another festival held every year in Edirne is the Pavli fair. The festival, which has been held in Pehlivanköy since 1910 for commercial purposes, became an entertainment center for the Marmara region. Many visitors from outside the province come to the fair held in September (Erbay, 2016). At the International Band and Liver Festival, which has been a celebration since 2010, the most famous gastronomic product of Edirne is served to the guests, and many band members who participate in the festival offer music feas ts to the festival participants (Edirne Municipality, 2019). The villages inhabited by the Turkish population migrating from various Balkan countries to Edirne at different dates offer charm in terms of their cultural values and rural tourism (Ceylan, 2009). Edirne is a city open to many domestic and foreign tourists with its tourism potential (Boyacioğlu, 2014). In terms of domestic tourism, summer houses, tents and camping areas also serve sea tourism. It is expected that more foreign tourists will come to Enez district and its vicinity with the opening of Enez Yacht Harbor and Fisherman's Shelter and Thessaloniki, Alexandroupolis ports and mutual yacht tourism. 


\section{MATERIALS AND METHODS}

\section{Purpose, Importance and Limitations of the Research}

The main purpose of this study is to determine how foreign tourists coming to Edirne evaluate the communication skills of the tradesmen operating in Ali Pasha Bazaar, Bedesten Bazaar and Arasta Bazaar. Another aim of the study is to determine whether there are significant differences in the perception of the communication skills of the tradesmen and the demographic characteristics of the foreign tourists visiting Edirne in 2019. In addition, the relationship between the foreign tourists' evaluation of the communication skills of the tradesmen and their satisfaction with the tradesmen's communication will be discussed in the study.

The research is important in terms of revealing how foreign tourists coming to Edirne evaluate the communication skills of tradesmen in historical bazaars and whether there are significant differences according to demographic characteristics. It is also important in the literature since it is the first study conducted in Edirne to evaluate the communication skills of the tradesmen.

There are some limitations in this research, as in every research in the field of social sciences. This study is limited to foreign tourists who visited the historical Ali Paşa Bazaar, Bedesten Bazaar and Arasta Bazaar in Edirne between 25 May 2019 and 15 July 2019. Apart from this, due to time and cost problems, foreign tourists could only be reached during these periods.

\section{The population and Sample of the Research}

The population of this research is foreign tourists coming to Edirne. As a result of the 2018 data obtained from the Edirne Provincial Directorate of Culture and Tourism, the number of foreign tourists who come to Edirne city center and spend at least one night is 375.926 . In this respect, while the number of required samples should be 384 for the population (Yazıcioğlu and Erdoğan, 2004), as observed in several researches due to research limitations such as time constraints (Kline, 2011), it is deemed sufficient that the number of statements used in the scale should be at least more than 10 times. The number of statements used in the survey is 25 and the minimum number of surveys to be collected from foreign tourists should therefore be 250 . In this study, the number of surveys collected from foreign tourists is 300 and the number of surveys which are not available is 17 and the remaining 283 questionnaires are analyzed. The number of surveys (283> 250) in this case shows that the sample is sufficient.

\section{Research Problem and Hypothesis}

Tradesmen offering tourist products in tourism and tourists who receive tourist product service are also human. If human relationships are strong and based on trust, the level of mutual satisfaction will increase. The communication skills of tradesmen marketing local products such as souvenirs, which are an important sector in the tourism market, must be extremely good in the eyes of the tourists and as a result of this situation, the image of the destination is provided in a positive direction. Edirne, which has recently become an import ant center of attraction for Greek and Bulgarian tourists, has to be protected and developed for the future to be transferred to the future due to the cultural heritage and attractive shopping opportunities it offers in the historical bazaars. In this context, how the communication skills of tradesmen producing or presenting touristic products are evaluated by tourists is very important (Sojkin et al., 2012). In this respect, it is necessary to conduct a research on how the communication skills of tradesmen are evaluated by foreign tourists.

There are some similar studies in the literature, although it is not the same as how foreign tourists evaluate the communication skills of tradesmen. According to Kuosuwan (2016), communication skills of tourism workers in Bangkok were found to be low. With the idea that foreign tourists perceive the communication skills of tradesmen and that these perceptions have an effect on the satisfaction of the tradesmen's ability to communicate with them, the hypothesis " $H_{1}$ : There is a relationship between the evaluation of the foreign tourists of the tradesmen's communication skills and the satisfaction of the tradesmen with their ability to communicate with them." has been created.

There are some studies in the literature suggesting that there are differences according to demographic characteristics in individuals' evaluation of communication skills. Accordingly, it has been observed that there are significant differences in the evaluation of persons' communication skills based on gender in the studies by Korkut (2005), Gölönü and Karc1 (2010), Mirzaei and Heidari (2012); based on age in the studies by Timcheva (2017), Sugito et al., (2017), Karalar (2018); based on education status in the studies by Karalar (2018) and based on the monthly income status in the study by Karalar (2018). In line with these results in the literature, the following hypotheses have been formed in order to analyze whether foreign tourists differ in their evaluation of the communication skills of trades according to gender, marital status, country of residence, education level, age, monthly income and professional status.

- $\mathrm{H}_{2}$ : There is a significant difference in the evaluation of the communication skills of tradesmen by foreign tourists according to their gender.

- $H_{3}$ : There is a significant difference in the evaluation of the communication skills of the tradesmen by foreign tourists according to their marital status.

- $\mathrm{H}_{4}$ : There is a significant difference in the evaluation of the communication skills of the tradesmen by foreign tourists according to the country of residence.

- $H_{5}$ : There is a significant difference in the evaluation of the communication skills of the tradesmen according to their educational status.

- $H_{6}:$ There is a significant difference in the evaluation of the communication skills of tradesmen by foreign tourists according to their income status.

- $H_{7}$ : There is a significant difference in the evaluation of the communication skills of tradesmen by foreign tourists according to their age.

- $H_{8}$ : There is a significant difference in the evaluation of the communication skills of the tradesmen by foreign tourists according to their professions.

\section{Reliability and Normality of Research}

Reliability of a study can be measured using various methods such as Cronbach's Alpha $(\alpha)$ coefficient (Nakip, 2006). As a result of the reliability analysis, the general reliability coefficient of Cronbach's Alpha has been determined as $\alpha=0,832$ for the evaluation of communication skills of foreign tourists, which revealed that the scale is highly reliable (Özdamar, 2015).

Within the scope of the research, each statement of the scale, which measures the opinions of foreign tourists about the communication skills of tradesmen, has been subjected to normality test. Tabachnick and Fidell (2013) have stated that skewness and kurtosis values should change between -1.5 and +1.5 in order for the data to show normal distribution. When the skewness and kurtosis values of the obtained data are examined, it has been observed that they are between -1.5 and +1.5 and it has been understood that the scale questions used in the study showed normal distribution (Table 2). 


\section{RESULTS AND DISCUSSIONS}

In the results part of the study, the demographic characteristics of the foreign tourists participating in the survey, the evaluation of the foreign tourists regarding the communication skills of the tradesmen and whether these evaluations differ according to the demographic variables and the effect of these evaluations on satisfaction have been determined. When the demographic characteristics of the participants in Table 1 are examined, it is observed that the majority of the foreign tourists are 159 people and women (56.2\%). The majority of the tourists, (199-70.3\%), are married. When the age ranges are analyzed, it is observed that 70 people (24.7\%) are in the age range of 45-54 and 69 are in the age range of 35-44 (24,4\%), which constitute the majority of tourists. When education level is examined, it is observed that there are 112 people (39.6\%) tourists mostly from university graduates. In terms of monthly income, 139 people have a monthly income of EUR 2001-3000 (49.1\%). It is understood that the tourists are mostly private sector employees with 76 people (26.9\%). When the residence status is analyzed, it is seen that $63.6 \%$ of the foreign tourists (180 persons) come from Bulgaria.

Table 1. Demographic characteristics of foreign tourists

\begin{tabular}{|c|c|c|c|c|c|}
\hline Gender & Frequency (f) & Percentage (\%) & Educational Status & Frequency (f) & Percentage (\%) \\
\hline Female & 159 & 56,2 & Primary School & 21 & 7,4 \\
\hline Male & 124 & 43,8 & High School & 93 & 32,9 \\
\hline Marital Status & $\mathbf{f}$ & $\mathbf{\%}$ & University & 112 & 39,6 \\
\hline Married & 199 & 70,3 & Postgraduate & 57 & 20,1 \\
\hline Single & 84 & 29,7 & Income Status & f & Percent (\%) \\
\hline Country of Residence & $\mathbf{f}$ & $\mathbf{\%}$ & No income & 33 & 11,7 \\
\hline Bulgaria & 180 & 63,6 & $2001-3000$ Euro & 139 & 49,1 \\
\hline Greece & 103 & 36,4 & $3001-4000$ Euro & 75 & 26,5 \\
\hline Age & $\mathbf{f}$ & $\mathbf{\%}$ & Over 4001 Euro & 36 & 12,7 \\
\hline $18-24$ & 30 & 10,6 & Occupation & f & $\mathbf{\%}$ \\
\hline $25-34$ & 42 & 14,8 & Private sector & 76 & 26,9 \\
\hline $35-44$ & 69 & 24,4 & Civil Servant & 69 & 24,4 \\
\hline $45-54$ & 70 & 24,7 & Tradesmen & 25 & 8,8 \\
\hline $55-64$ & 36 & 12,7 & Retired & 53 & 18,7 \\
\hline 65 and above & 36 & 12,7 & Student & 19 & 6,7 \\
\hline Total & $\mathbf{2 8 3}$ & $\mathbf{1 0 0 , 0}$ & Other & 41 & 14,5 \\
\hline
\end{tabular}

Table 2. Evaluation of foreign tourists on communication skills of tradesmen and results of normal distribution test

\begin{tabular}{|c|c|c|c|c|}
\hline Statement Items & A. Avg. & Std. Deviation & Skewness & Kurtosis \\
\hline Tradesmen have trouble communicating their thoughts to me. & 2,73 & 1,266 & ,439 & $-1,016$ \\
\hline Tradesmen feel comfortable during the conversation. & 3,90 & 1,092 & $-1,257$ & 1,187 \\
\hline Tradesmen pay attention to whether I am open to the proposal. & 3,59 & 1,026 &,- 454 & $-0,368$ \\
\hline Tradesmen are trying to understand my feelings by empathizing with me. & 3,19 & 1,052 &,- 102 & $-0,582$ \\
\hline Tradesmen pay attention to me during shopping. & 3,55 & 1,052 &,- 560 & $-0,234$ \\
\hline Tradesmen give me enough time to listen to what I want to say. & 3,66 & 1,128 &,- 981 & 0,289 \\
\hline Tradesmen show that they don't like criticism & 2,63 & 1,139 & 215 & $-0,733$ \\
\hline When I communicate with tradesmen, I can easily deal with them & 3,05 & 1,194 &,- 216 & $-0,984$ \\
\hline Tradesmen are impatient during communication. & 2,59 & 1,089 & ,356 & $-0,447$ \\
\hline I feel that tradesmen are bored when they listen to me. & 2,77 & 1,275 & 269 & $-1,058$ \\
\hline Tradesmen are making statements to disrupt communication. & 2,65 & 1,236 & ,358 & $-0,948$ \\
\hline At the end of the discussion, tradesmen can accept that their arguments are wrong. & 2,95 & 1,212 & ,016 & $-0,933$ \\
\hline When the tradesmen speak to me, they make good sentences. & 3,37 & 1,111 &,- 351 & $-0,592$ \\
\hline Tradesmen respect my ideas even if they don't share the same opinion. & 3,52 & 1,099 &,- 364 & $-0,633$ \\
\hline Tradesmen do not listen to my words even though they look at me. & 2,75 & 1,098 & ,340 & $-0,503$ \\
\hline I'm happy to trust tradesmen. & 3,59 & 1,086 &,- 592 & $-0,240$ \\
\hline Tradesmen give me the right to speak. & 3,69 & 1,012 &,- 649 & 0,024 \\
\hline Tradesmen repeat things that I do not understand with new words. & 3,81 & 0,997 &,- 834 & 0,264 \\
\hline Tradesmen try to understand me. & 3,96 & 0,981 & $-1,094$ & 1,204 \\
\hline Tradesmen try to control people. & 3,18 & 1,129 &,- 233 & $-0,820$ \\
\hline Tradesmen listen to my suggestions. & 3,62 & 1,029 &,- 597 & 0,100 \\
\hline Tradesmen do not hurt my feelings when criticizing. & 3,55 & 1,158 &,- 700 & $-0,306$ \\
\hline \multicolumn{2}{|l|}{ General arithmetic average of all statements } & 3,30 & & \\
\hline
\end{tabular}

When Table 2 is examined, it is observed that the arithmetic average of all items related to the evaluation of the communication skills of the foreign tourists by the tradesmen is 3.30. It is understood that the statement which has the highest arithmetic average in the perception of foreign tourists towards the communication skills of the tradesmen is "Tradesmen are trying to understand me" and with an arithmetic average of 3.96, followed by "Tradesmen make me feel comfortable during the meeting" with an arithmetic average of 3.90. The scale item with the lowest arithmetic average is "Tradesmen behave impatiently during communication" with an arithmetic average of 2.59.

Table 3. Correlation Analysis

\begin{tabular}{|l|l|r|r|}
\hline & & Evaluation of communication skills of tradesmen & Satisfaction from communication \\
\hline \multirow{3}{*}{ Evaluation of communication skills of tradesmen } & PearsonCorrelation & 1 & \\
\cline { 2 - 4 } & Sig. (2-tailed) & $392^{* *}$ \\
\cline { 2 - 4 } & $\mathrm{N}$ &, 000 \\
\hline Satisfaction from communication & PearsonCorrelation & 283 &, $392^{* *}$ \\
\cline { 2 - 4 } & Sig. (2-tailed) &, 000 & 283 \\
\cline { 2 - 4 } & $\mathrm{N}$ & 1 \\
\hline
\end{tabular}


Correlation analysis was performed to determine the relationship between foreign tourists' point of view of the communication skills of tradesmen and their satisfaction with the ability of tradesmen to communicate with tourists (Table 3).

When Table 3 is analyzed, it is observed that there is a positive and moderate relationship between the perception of foreign tourists about the communication skills of the tradesmen and the satisfaction from tradesmen's skill to communicate with them (Kalayc1, 2010). Regression analysis has been conducted to determine whether there is any significant effect of the perception of foreign tourists on the communication skills of the tradesmen and the satisfaction with the communication skills of the tradesmen. Before starting the analysis, the arithmetic averages of the 24 statements asked about the perception of foreign tourists about the communication skills of the trades were reduced to a single dimension and then regression analysis was started.

Table 4. Regression Analysis Results

\begin{tabular}{|l|c|c|c|}
\hline Independent variables & $\boldsymbol{\beta}$ & $\mathbf{t}$ & $\mathbf{p}$ \\
\hline Perceptions of foreign tourists on the communication skills of tradesmen & $\mathbf{8 1 5}$ & $\mathbf{7 , 1 4 8}$ & $\mathbf{, 0 0 0}$ \\
\hline $\mathrm{R}^{2}=0,151 \mathrm{~F}=51,094 \quad \mathrm{p}=0,000 * \mathrm{p}<0,01$ \\
\hline$*$ The dependent variable: Satisfaction with the communication of tradesmen \\
\hline
\end{tabular}

The result of the regression analysis done to determine the effect of the perceptions of foreign tourists on the communication skills of the tradesmen indicate that, as observed in Table 4, R value is $0,392, R 2$ value is 0,154 and corrected $R 2$ value is 0,151 . Since the $R 2$ value is closer to zero, it can be said that there is a relationship between the perception of foreign tourists about the communication skills of the tradesmen and the satisfaction from the communication of tradesmen. In addition, the F value of 51,094, such as the value of "P" probability value is less than 0.05 can be said to be a significant relationship between the components of the model. As a result of the analysis, the explanatory power of the model is 0,15 and it shows that $15 \%$ of the variation of satisfaction from the communication of tradesmen can be explained by the perception of foreign tourists about the communication skills of tradesmen. The t-test and one-way ANOVA analyses have been conducted in order to determine whether the evaluations of the foreign tourists regarding the communication skills of the tradesmen differed according to their demographic characteristics. As a result of significant differences, Tukey test has been performed post-hoc. In addition, eta square (n2) values have been calculated by using effect size analysis for significant differences.

Table 5. T-test analysis of foreign tourists for evaluating the communication skills of tradesmen

\begin{tabular}{|c|c|c|c|c|c|c|c|c|}
\hline & & Gender & $\mathbf{N}$ & Average & Standard Deviation & $\mathbf{F}$ & p* & $\mathbf{t}$ \\
\hline \multirow{2}{*}{ Gender } & \multirow{2}{*}{$\begin{array}{l}\text { Evaluation of foreign tourists on the } \\
\text { communication skills of tradesmen }\end{array}$} & Female & 159 & 3,3071 & 0,493 & \multirow{2}{*}{0,025} & \multirow{2}{*}{0,686} & \multirow{2}{*}{0,425} \\
\hline & & Male & 124 & 3,2826 & 0,522 & & & \\
\hline \multirow{2}{*}{ Marital Status } & \multirow{2}{*}{$\begin{array}{l}\text { Evaluation of foreign tourists on the } \\
\text { communication skills of tradesmen }\end{array}$} & Married & 199 & 3,29 & 0,555 & \multirow{2}{*}{9,773} & \multirow{2}{*}{0,919} & \multirow{2}{*}{, 102} \\
\hline & & Single & 84 & 3,30 & 0,359 & & & \\
\hline Country of Residence & $\begin{array}{l}\text { Evaluation of foreign tourists on the } \\
\text { communication skills of tradesmen }\end{array}$ & Bulgaria & 180 & 3,28 & 0,502 &, 169 & 0,408 &,- 829 \\
\hline
\end{tabular}

The t-test analyses have been conducted to determine whether there are significant differences in the evaluation of foreign tourists' tradesmen's communication skills according to gender, marital status and country of residence (Table 5). As a result of the analyses, it has been determined that there was no significant difference between the evaluations of foreign tourists regarding the communication skills of trades according to gender, marital status and country of residence and accordingly, $\mathrm{H}_{2}, \mathrm{H}_{3}$ and $\mathrm{H}_{4}$ hypotheses have been rejected.

Table 6. One-way ANOVA analysis for foreign tourists to evaluate the communication skills of tradesmen

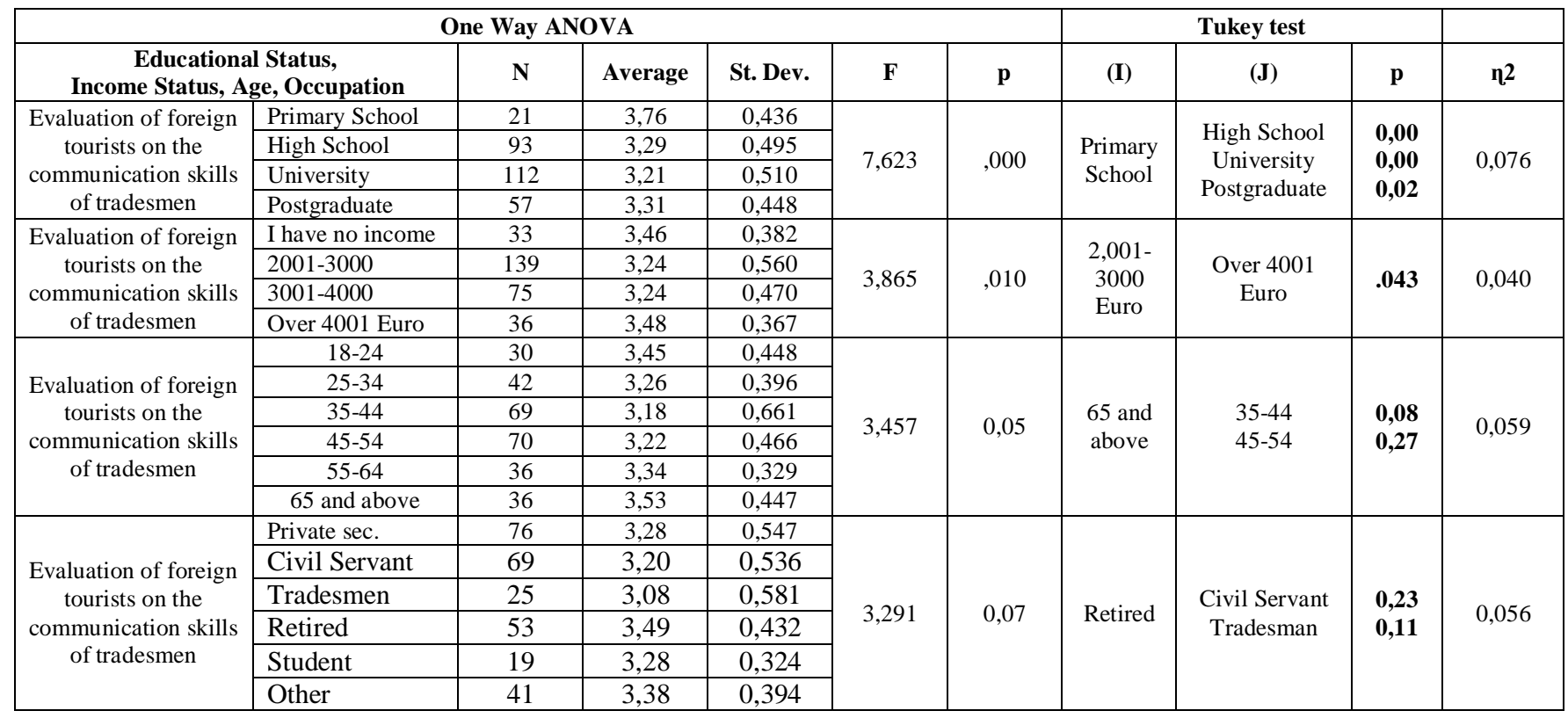

As can be observed in Table 6, one-way ANOVA analysis has showed that there are significant differences in the evaluation of the communication skills of the trades according to their education, income, age and professional status. Tukey test has been used to determine which education level this difference was between. According to the Tukey test, there were significant differences between the graduates of primary education and high school, university and graduates regarding their communication skills and this difference is in fa vor of primary education graduates. According to the Tukey test made between income levels, there are significant differences in the evaluation of 
communication skills of tradesmen with income between 2001-3000 Euro and 4001 Euro and above, and this difference is in favor of those with income between 2001-3000 Euro.As a result of the Tukey test made between the ages, it has been found that there are significant differences in the evaluation of the communication skills of tradesmen between the ages of 65 and over and between the ages of 35-44 and 45-54, and this difference is in favor of those aged 65 and over. According to the Tukey test made between occupational status, there are significant differences between retired and civil servants and tradesmen in terms of their communication skills and this difference is in favor of retired foreign tourists. Because of all these results, $\mathrm{H}_{5}, \mathrm{H}_{6}, \mathrm{H}_{7}$ and $\mathrm{H}_{8}$ hypotheses have been accepted.

In addition to these results, in order to determine the relationship level of the foreign tourists in Table 6 regarding the communication skills of tradesmen and demographic characteristics (education, income, age and occupation) variables, effect size analyses are performed. According to Cohen (1988), if the effect size is between $0.01<\eta 2<0.06$, it means minor, if it is between $0.06<\eta 2<0.14$, it means moderate and $0.14<\eta 2<+$ means broad effect. As a result of the evaluation of the foreign tourists' communication skills, the eta square value of education level (762) is found to be 0.076 and the effect area is found to be moderate. Again, with the evaluation of communi cation skills of foreign tourists, monthly income status eta square value (n2) is found to be 0.040 and the effect area is found to be minor. In addition, with the evaluation of communication skills of foreign tourists, the eta square value (n2) of the age is found to be 0.059 and the effect area is found to be minor. Finally, with the evaluation of communication skills of foreign tourists, eta square value (n2) of occupations is found to be 0.040 and the effect area is found to be small.

\section{CONCLUSION AND SUGGESTIONS}

Communication is a concept that continuously increases its importance from past to present because communication is essential in life. In the same way, the person transfers his/her thoughts and feelings to the other person through communicating (Atan, 2016). Since it is a people-oriented area in the tourism sector, the concept of communication is extremely important. As a result of the good relations established by the employees in the sector with the tourists, the satisfaction of the customer increases and as a result, the profit of the company increases with long term customer loyalty, advice to others (WOM, e-wom, etc.) and desire to spend more.

In the literature, several researches have been made to measure the communication skills of university students (Pelit and Karaçor, 2015), vocational high school teachers (Küçüksüleymanoğlu and Çetinkaya, 2014), teaching staff (Keçeci and Taşocak, 2009), hotel business employees (Olcay et al., 2014), hotel business managers (Erol, 2006), tour guides (Alshatnawi, 2014) and managers' effective leadership (Barker, 2011). In this research, foreign tourists' evaluations regarding the communication skills of tradesmen are discussed.

$56.2 \%$ of the foreign tourists participating in the survey are women and $70.2 \%$ are married. It is observed that $49.1 \%$ of foreign tourists consist of middle-aged people aged 35-54, 39.6\% are university graduates, almost half (49.1\%) has monthly incomes of 2001-3000 Euro and $26 \%, 9$ of them are private sector employees. It has been found that $26 \%$ of the foreign tourists are mostly employed in the private sector and $63.6 \%$ of them reside in Bulgaria. According to the results of the study, it has been determined that the level of communication skills of foreign tourists is good. This is similar to the studies of Karalar (2018) and Olcay et al., (2014). In addition, it has been found that the evaluation of the communication skills of the foreign tourists by the tradesmen has an effect on the satisfaction of the communication skills of the tradesmen. Again, it has been found that the evaluation of the communication skills of the tradesmen by foreign tourists does not differ according to gender, marital status and country of residence. This result found by gender does not correlate with the studies of Korkut (2005), Gölönü and Karcı (2010), Mirzaei and Heidari (2012), Timcheva (2017), Sugito et al., (2017); while it correlates with the studies of Küçüksüleymanoğlu and Çetinkaya (2014). According to the marital status, this result is not similar to the result of Karalar (2018).

The other important results of the study are that there are significant differences in the evaluation of communication skills of the foreign tourists according to their education, age, income and professional status. In the light of these results, there are similar studies based on age (Karalar, 2018), based on educational background (Erol, 2006; Mocanu and Deaconu, 2017; Karalar, 2018) and based on their monthly income (Karalar, 2018) in which similar results have been obtained. In addition, the effect size of the groups with different education, income, age and occupational statuses has been examined for eta (n) eta square (n2) values and it has been found that the educational level was moderately effective for other groups (income, age and occupational status). As a result of the research, it is useful to present a number of suggestions to professionals and researchers. The population of the study consists of foreign tourists coming to Edirne province. In cities where the tourism sector is more intense and the sample can be increased more, it may be suggested to conduct studies to measure the communication skills of the employees with the tourists. In the following researches, it can be done to measure the communication skills of tradesmen operating in the historical Alipaşa Bazaar, Bedesten Bazaar and Arasta Bazaar in Edirne.

\section{REFERENCES}

Alshatnawi, E.A.R. (2014). Assessing Communication Skills among Jordanian Tour Guides: German Tourists Perceptions. Journal of Management Research, 6(1), 1-11.

Akay, B., Tokatlı, C., \& Aksoy, M. (2017). A study of evaluating tourism potential Kirklareli and Edirne provinces. Kirklareli University Journal of Social Science, 1, 89-102.

Atan, A. (2016). The effects of family communication skills psychoeducational program on parents' communication skills, dyadic adjustment, marital satisfaction and their 5-6 yearsold children's social-emotional adjustment. Unpublished MSc Dissertation, University of Pamukkale, Turkey.

Bahar, O., \& Kozak, M. (2005). Comparions of tourism competitiveness between Turkey and Mediterranean countries. Anatolia: Journal of Tourism Research, 16(2), 139-152.

Baltaş, Z., \& Baltaş, A. (1992). Body Language. İstanbul: Remzi Publication.

Barker, A. (2011). Improve your communication skills. London: Kogan Page Limited.

Bilar, E. (2015). UNESCO world cultural heritage of Edirne: Selimiye Mosque Complex. Turk Neurosurgery, 25(2), $197-200$.

Bolat, S. (1996). Communication in educational organizations: Application in Hacettepe University Faculty of Education. Hacettepe University Journal of Education, 12, 75-80.

Boone, L.E., \& Kurtz, D.L. (1978). Management. New York: Random House Business Division.

Boyacıoglu, E.Z. (2014). Women's Entrepreneurship in rural tourism: Sample of Edirne. International Journal of Social and Economic Sciences, 4(2), 82-90.

Briggs, S., Sutherland, J., \& Drummond, S. (2007). Are hotel serving quality an exploratory study of service quality in the Scottish hotel sector. Tourism Management, 28, 1006-1019.

Brown, D.F. (2005). The significance of congruent communication in effective classroom management. Clearing House: A Journal of Educational Strategies, Issues and Ideas, 79(1), 12-15.

Cadotte, E.R., Woodruff, R.B., \& Jenkins, R.L. (1987). Expectations and norms in models of consumer satisfaction. Journal of Marketing Research, $24(3), 305-314$.

Can, C.C., \& Bilar, E. (2009). Bibliography of Edirne. Edirne: Trakya University Rectorate Publications. URL: http://acikarsiv.trakya.edu.tr/bibliyografya/ bibliyografya.pdf, accessed 21.10.2019.

Ceylan, S. (2009). Touristic attractions of Enez (Edirne) and the evaluation of these attractions regarding maintainable tourism. Paper presented at the V. National Geography Symposium, $16^{\text {th }}-17^{\text {th }}$ October 2009 , Ankara.

Cohen, J. (1988). Statistical power analysis for the behavioral sciences. New York: Lawrence Erlbaum Associates Publishers. 
Collier, B., Mcghier-Richmon, D., \& Self, H. (2010). Exploring communication assistants as an option for increasing communication access to communities for people who use augmentative communication. Augmentative and Alternative Communication, 26(1), 48-59.

Cronin, J.J., \& Taylor, S.A. (1992). Measuring service quality: A re-examination and extension. Journal of Marketing, 56, 55-68.

Davis, M.H. (1983). Measuring individual differences in empathy: Evidence for a multidimensional approach. Journal of Personality and Social Psychology, year 44, 113-126. https://doi.org/10.1037/0022-3514.44.1.113

Day, G.S. (1994). The capabilities of market-driven organizations. Journal of Marketing, (58)4, 37-52.

Deniz, A.G.K. (2003). The situation of $5^{\text {th }}$ grade students living in cities and villages in respect of writing composition skills. Journal of Turkology Research, (13), 233.

DeVitto, J.A. (2004). Essentials of Human Communication. Pearson Education, Inc.

Edirne Governorship (2005). Edirne Province Yearbook. İstanbul: Acar Publication.

Erbay, E., Demirkol, C., \& Yıldırım Özmutlu, S. (2016). The effects of festival, fair and fair organizations in the Thrace region on the socio-economic structure of the region. Namık Kemal University Scientific Research Project, NKUBAP.00.13.AR.12.03.

Erdogan, E., \& Kuter, N. (2010). The evaluation of the cultural values of Edirne city in the frame of urban aesthetics. Journal of Tekirdag Agricultural Faculty, 7(3), 137-145.

Erdönmez Cobanlı, I. (2019). Verbal communication within the context of circular communication process. Near East University International Journal of Art, Culture and Communication, 2(1), 81-99.

Erkuş, A., \& Günlü, E. (2009). The effects of communication style and non-verbal communication level on employees' work performance: A research in five star hotel establishments. Anatolia: A Journal of Tourism Research, 20(1), 7-24.

Erol, N. (2006). An investigation to define the communication lvel of internal communication in four or five starred hotels. Unpublished MSc Dissertation, University of Abant İzzet Baysal, Bolu, Turkey.

Eyice, S. (1993). Main events in the history of Edirne during the Byzantine period. Ankara: Turkish History Foundation Publication.

Fiske, J. (1996). Introduction to communication science. S. İrvan (Translated.). Ankara: Ark Publication.

Gizerler, M. (2004). Turkish cuisine and our food culture from Edirne. Edirne Governorate Publication.

Gökçe, O. (2006). Communication science anatomy of human relations. Ankara: Siyasal Publication.

Gölönü, S., \& Karcı, Y. (2010). Vocational high school students' communication skills communication levels (Sample Ankara). Journal of Communication Theory \& Research, 31, 123-140.

Günlü, E. (2001). Factors limiting effective communication in tourism businesses and the importance of communication. Dokuz Eylül University Journal of Social Science, 3, 154-163.

Hamzadayı, E., \& Cetinkaya, G. (2011). Peer feedbacks in revision of written expressions: Feedback types, students' perceptions. Journal of Abant Izzet Baysal University Faculty of Education, 1(1), 147-165.

Heybeli, N. (2009). Sultan Bayezid Kulliyesi one of the earliest medical schools founded in 1488. Clinical Orthopaedics and Related Research, 467(9), $2457-2463$.

Hui, T., Wan, D., \& Wan, A. (2007). Tourists satisfaction, recommendation and revisiting Singapore. Tourism Management, 28, 965-975. https://doi.org/10.1016/j.tourman.2006.08.008

Johnson, M.B. (1999). Communication in the classroom. URL: https://eric.ed.gov/?id=ED436802, accessed: 21.10 .2019$.

Jones, T.O., \& Sasser, W.E. (1995). Why satisfied customers defect. Harvard Business Review, 73, 88-99.

Kalaycı, Ş. (2010). SPSS applied multivariate statistical techniques. Ankara: Asil Publication.

Kang, J., \& Hyun, S.S. (2012). Effective communication styles for the customer-oriented service employee: Inducing dedicational behaviors in luxury restaurant patrons. International Journal of Hospitality Management, 31, 772-785.

Kar, Z. (2002). Edirne, the city of history and culture. Edirne: Edirne Valiliği Publication.

Karalar, F. (2018). A study on the evaluation of the communication skills of the tradesmen in Almact Market and Bakırclar Bazaar by themselves and local tourists. Unpublished MSc Dissertation, University of Gaziantep, Turkey.

Keçeci, A., \& Taşocak, G. (2009). Communication skills of faculty’s: An example of a college of nursing. Dokuz Eylul University E-Journal of Nursing Faculty, 2(4), 131-136.

Kline, R.B. (2011). Principles and practice of structual equation modeling, Third edition, New York: The Guil XYZ Press

Korkut, F. (2005). Communication skills training program for adults. Hacettepe University Journal of Education, 28, 143-149.

Krishnan, S.G., \& Wesley, J.R. (2013). A study on impact of employee engagement level. International Research Journal of Business and Management, 6, 54-64.

Kuosuwan, B. (2016). The readiness of english communication skills of tourism employees in Bangkok for entering the ASEAN community. International Journal of Environmental and Science Education, 12903-12907.

Küçükaltan, D., Oğuzhan, A., Apak, S., \& Boyacıoğlu, E,Z. (2005). The effect of cultural tourism on regional development: example of Kırkpınar oil wrestling. Trakya University Journal of Social Sciences, 6(1), 1-22.

Küçüksüleymanoğlu, R., \& Çetinkaya, E. (2014). Communication competencies of the vocational teachers-case study: Yıldırım trade vocational high school. Adiyaman University Journal of Social Sciences, 7(16), 327-365.

Lazar, J. (2001). Communication Science. C. Anık (Translated). Ankara: Vadi Publication.

Littlejohn, W.S., \& Foss, K.A. (2011). Theories of human communication. Illinois: Waweland Press.

Masa'deh, R., Alananzeh, O., Jawabreh, O., Alhalabi, R., Syam, H., \& Keswani, F. (2019). The association among employees' communication skills, image formation, and tourist behaviour: Perceptions of hospitality management students in Jordan. International Journal of Culture, Tourism, and Hospitality Research. 13(3), 257-272.

Mansel, M.A. (1993). Edirne in ancient times. Ankara. Turkish History Foundation Publication.

Mavis, İ., Togram, A.A., \& Togram, B. (2010). Assessing speech and language services at a university research center in Turkey: consumer satisfaction. Anadolu University Journal of Social Sciences, 10(2), 165-184

Misirlı, İ. (2007). General and technical communication. Ankara: Detay Publication.

Misırlı, N., Kiper, T., \& Korkut, A. (2019). Identification of natural and cultural city identities: Edirne province Karaağaç neighborhood example. Journal of Bartın Faculty of Forestry, 21(1), 52-65.

Mirzaei, A.. \& Heidari, N. (2012). Exploring the use of oral communication strategies by (non)fluent L2 speakers. The Journal of Asia TEFL, 9(3), $131-156$.

Mocanu, E.M., \& Deaconu, A. (2017). The use of information and communication tecnology as a teaching method in vocational education and training tourism. Acta Didactica Napocensia, 10(3), 19-34.

Nakip, M. (2006). Pazarlama araştırmalart, teknikler ve ( SPSS Destekli) Uygulamalar, Seçkin Publication.

O'Hair, D., Gustav, W.F., \& Dixon, L.D. (2005). Strategic communication in business and the professions. Boston: Houghton Mifflin Company.

Olcay, A., \& Giritlioğlu, İ. (2014). A research on customer satisfaction in hotels serving tourism in the Gaziantep region. Electronic Journal of Social Sciences, 13(50), 1-22.

Olcay, A., Giritlioğlu, İ., \& Çıkmaz, E. (2014). Communication sufficiency level of the hotel staff: A research in Gaziantep region. Journal of Business Research-Türk, 6(1), 385-403.

Özdamar, K. (2015). Statistical data analysis with package programs. Eskișehir: Nisan Publication.

Parlayan, M.A., \& Dökme, S. (2016). Evaluation of nurse and patients' communication levels in private hospitals: an example of hospital, Kahramanmaraş Sütçü Imam University Journal of Social Sciences, 13(2), 265-285.

Pearce, B.W. (1989). Communication and the human condition. URL: https://books.google.com.tr/books?printsec=frontcover\&vid=LCCN88030565 \&redir_esc $=\mathrm{y} \# \mathrm{v}=$ onepage $\& \mathrm{q} \& \mathrm{f}=$ false accessed: 20.10 .2019$)$

Pelit, E., \& Karaçor, M. (2015). T A study on tourism students' communication skills: Afyon Kocatepe University example, Gaziantep University Journal of Social Sciences, 14(4), 847-872. 
Poon Teng Fatt, J. (1998). Nonverbal communication and business success. Management Research News, 21(4/5), 1-10.

Ruesch, J., \& Bateson, G. (1951). Communication: The social matrix of psychiatry. New York: Norton.

Sezgin, M., \& Akgöz, E. (2009). General and technical communication. Ankara: Gazi Publication.

Shabir, S., \& Sharma, R. (2019). Role of soft skills in tourism industry in Saudi Arabia. International Journal of Engineering and Management Research, 9(4), 87-92.

Shannon, C.A., \& Weaver, W. (1949). The mathematical theory of communication. Urbana: Illinois Publication.

Sojkin, B., Bartkowiak, P., \& Skuza, A. (2012). Determinants of higher education choices and student satisfaction: The case of Poland. Higher Education, $63(5), 565-581$

Sugito, S., Susilowati, S.M.E., Hartono, H., \& Supartono, S. (2017). Enhancing students' communication skills through problem posing and presentation. International Journal of Evaluation and Research in Education, 6(1), 17-22.

Tabachnick, B.G., \& Fidell, L.S. (2013). Using multivariate statistics. Pearson: Boston.

Stewart H., Hope C., \& Muhlemann A. (1998). Professional service quality a step beyond other services. Journal of Retailing and Consumer Services, 5(4), 209-222.

Taylor, J. (1998). Imperial Istanbul'a traveller's guide includes İznik, Bursa and Edirne. London: I.B. Tauris and Co. Ltd.

Thayer, L.O. (1961). Administrative communication. URL: https://archive.org/details/administrativeco00thay/page/n5 accessed: 16.10 .2019

Timcheva, E. (2017). Intercultural communication: The communication between Turks and Macedonians living in Macedonia. Unpublished MSc Dissertation, University of Anadolu, Eskişehir, Turkey.

Tutar, H., Yılmaz, K., \& Erdönmez, C. (2003). General and technical communication. Ankara: Nobel Publication.

Usal, A. (2006). Edirne history and culture. Edirne Vergi Dairesi Başkanlı̆̆l Publication. URL: http://www.edirnevdb.gov.tr/kultur/pdf/Edirne_Tarihi_ Kulturu.pdf accessed: 15. 05. 2019.

Uzuntas, A. (2013). Effective communication: explaining and understanding. Kastamonu Education Journal, 21(1), 11-30.

Vasanthakumari, S. (2019). Soft skills and its application in work place. World Journal of Advanced Research and Reviews, 03(02), 066-072.

Yazıcıoğlu, Y., \& Erdoğan, S. (2004). SPSS uygulamalı bilimsel araştırma yöntemleri. Ankara: Detay Publication.

Yılmaz, V., \& Çatalbaş, K.G. (2007). The effect of the perception about credit cards on customer pleasure and loyalty. Finance Politics \& Economic Reviews, 44(513), 83-94

Zairi, M. (2000). Managing customer satisfaction: A best practice perspective. The TOM Magazine, 12(6), 389-394.

*** Edirne Municipality (2019). 9th International Edirne Marching and Liver Festival. URL: http://www.edirne.bel.tr/9-uluslararasi-edirne-bando-ve-cigerfestivali basladi/11841/ accessed 22.09.2019.

Article history: $\quad$ Received: 19.03.2020 Revised: 22.04

Accepted: 27.05.2020

Available online: 08.07.2020 